\title{
Water: A Major Stake of Conflicts in the Twenty-First Century
}

\author{
Benjamin Mwadi Makengo $\left.{ }^{(}\right)$, Joseph Mimbale Molanga ${ }^{\circledR}$, Jean-Marie Mbutamuntu $(\mathbb{0}$, \\ Patience Kamanda Londo (1), Théo-Macaire Kaminar Nsiy \\ University of Kinshasa, Kinshasa, DRC \\ Email: benjaminmwadi@yahoo.com, joseph_mimbale@yahoo.com,fxmasena@yahoo.com, lkamanda71@yahoo.fr, \\ kaminarmacaire@gmail.com
}

How to cite this paper: Makengo, B. M., Molanga, J. M., Mbutamuntu, J.-M., Londo, P. K., \& Nsiy, T.-M. K. (2021). Water: A Major Stake of Conflicts in the Twenty-First Century. Open Journal of Social Sciences, 9, 125-148.

https://doi.org/10.4236/jss.2021.911011

Received: October 22, 2021

Accepted: November 20, 2021

Published: November 23, 2021

Copyright $\odot 2021$ by author(s) and Scientific Research Publishing Inc. This work is licensed under the Creative Commons Attribution International License (CC BY 4.0).

http://creativecommons.org/licenses/by/4.0/

\section{(c) (i) Open Access}

\begin{abstract}
The need to ensure freshwater security remains sacrosanct to the survival and security of humanity. While various studies on water security continue to draw the world's attention to future threats and risks against humanity's better survival and security-following the current management of our various waterways. It is in this light that this paper proposes to explain why access to water may well be a major stake of conflicts in this 21 st century. After debate and discussion, the results that emerge from this paper show that the multiplication of threats arising from climate change, which continues to worsen in this century, coupled with the hybrid policies and activities of various actors at stake, and combined with the singular characteristics of water-including, notably, a resource that guarantees our existence, a scarce resource, an unevenly distributed resource, and a resource that is shared among several states, nationalities and social categories-emerge two fundamental implications. The first is that of the great need for cooperation between riparian states, nationalities and various social categories; and the second is that exhibits the great likelihood of conflicts between them-to the competing uses of the shared water resource and the conquering spirits of one another. By using a few cases of bellicose rhetoric on the Tigris-Euphrates, Jordan, Indus, Syr-Daria, Nile, Congo, Colorado and Rio Grande watersheds, this paper makes a bitter observation of the predominant tendency of the second implication-the conflictual one-over the first-the cooperative one-in this twenty-first century that ostensibly denotes that water should be taken seriously as a major stake of conflicts in this century. Thus, this paper considers that it is important and time for humanity to promote transboundary water cooperation between states and nationalities of shared river basins; and integrated water management in the steps of good governance at all levels, in the sense of avoiding a flare-up of the situation and limiting to the maximum a worsening where the violins do not agree anymore.
\end{abstract}




\section{Keywords}

Water Conflicts, Climate Change, Major Stake of Twenty-First Century, Water Scarcity, Water War

\section{Introduction}

The water war has long been a subject of doctrinal controversy (Wolf, 1998; Wolf et al., 2005; Bernauer, Bohmelt, \& Koubi, 2012; Mirumachi, 2015; De Stefano et al., 2010; Gleick, 1993; Larry, 2015; Petersen-Perlman, Veilleux, \& Wolf, 2017). It opposes those who see water as an issue of conflict (Reuveny \& Maxwell, 2001; Larry, 2015) to the group of scholars who see water more as an issue of cooperation (Ayeb, 1998; Wolf, 1998; Larry, 2015). It is obviously not our intention here to enter into this doctrinal controversy, our central objective being to answer the question of why access to water is likely to be a major stake of conflict in this twenty-first century. A question that continues to interest various scholars around the world, each of whom brings its explanatory contribution on it. For the sake of clarity and synthesis, we were more interested to the first explanations that come from the work of Wolf (1998) who, through Figure 1 below, was able to restore all the possible interactions around transboundary rivers in the world, and water in general.

After having listed and scrupulously examined all the known conflicts that have opposed at least two states over the last seventy years, in more than 260 river basins, Wolf observes that there have actually been only seven water wars since the Second World War [between India and Pakistan in 1948, Israel and Syria in 1951 and again in 1953; Egypt and Sudan in 1958, Ethiopia and Somalia between 1963 and 1964; Iraq and Syria in 1975; Senegal and Mauritania between 1989 and 1991]. In contrast, 145 water treaties were signed during the same period. Rather, when one observes at first sight the plausibility of the hypotheses put forward by Wolf, with, in support, an idyllic image of cooperation that these 145 agreements concluded on various shared watercourses suggest, one risks obscuring, in many respects, the lively tensions experienced by certain States, certain regions of the world, [to mention here only the cases of the Middle East, North Africa, Central Asia, South Asia, North America...]. Moreover, everything leads us to believe today that water war is a geopolitical reality that is increasingly unavoidable, if nothing is done, and it is an existential issue in the short term. According to a UN report, water scarcity currently affects nearly 700 million people in 43 countries around the world. In 2025, 1.8 billion people will live in countries or regions affected by a complete water shortage and two thirds of the world's population could be living under water stress conditions (United Nations, 2020). According to the current climate change scenario, nearly half of the world's population will be living in areas of high water stress by 2030, including between 75 and 250 million people in Africa. In addition, water scarcity 


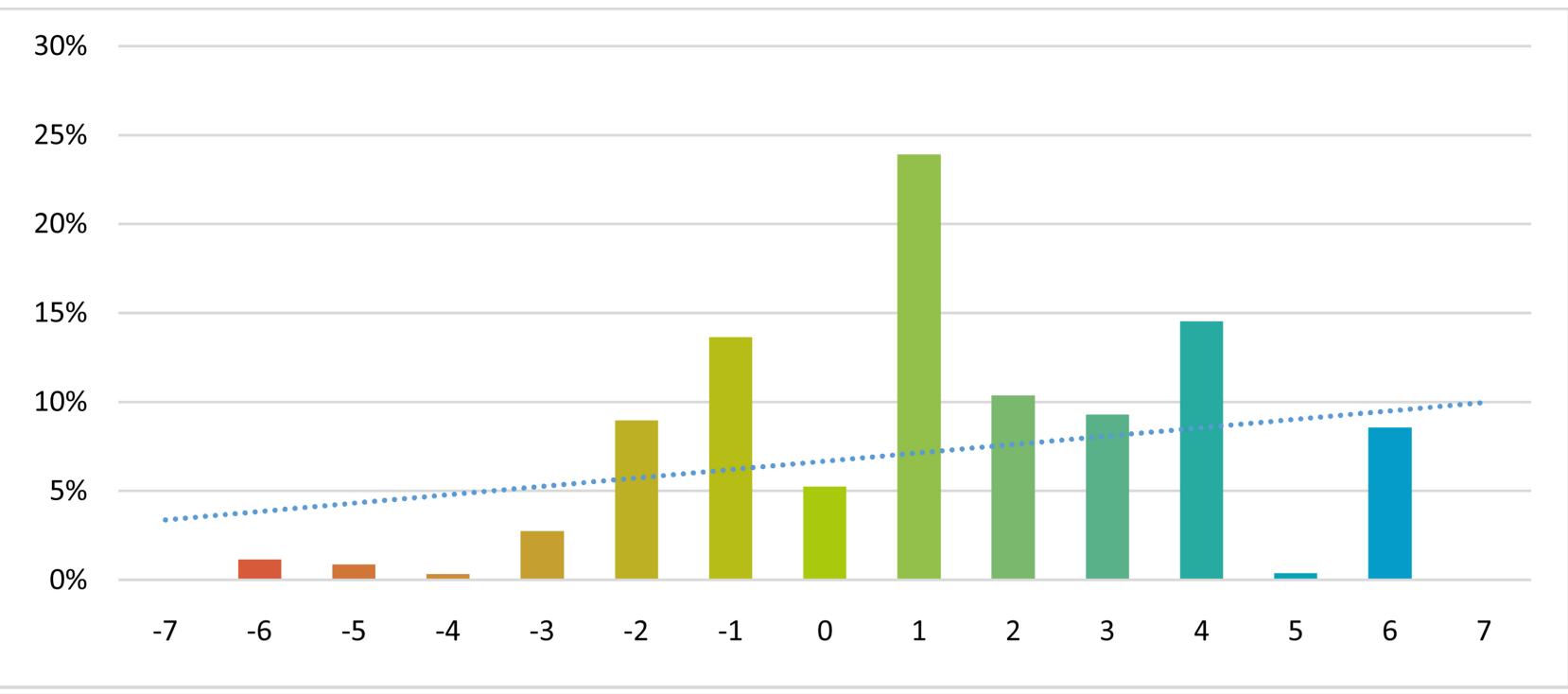

Chart legend:

$\begin{array}{lc}\text { Declared war } & 0 \% \\ \text { Important military action } & 1 \% \\ \text { Small-scale action } & 1 \% \\ \text { Hostile military policy action } & 0 \% \\ \text { Hostile diplomatic/economic action } & 3 \% \\ \text { Official/strong verbal hostility } & 9 \% \\ \text { Average unofficial verbal hostility } & 14 \% \\ \text { Non-significant neutral action } & 5 \% \\ \text { Medium verbal support } & 24 \% \\ \text { Official verbal support } & 10 \% \\ \text { Cultural support, scientific agreement } & 9 \% \\ \text { Non-military technical economic industrial agreement } & 15 \% \\ \text { Military economic strategy support } & 0 \% \\ \text { International Water Treaty } & 9 \% \\ \text { Unification into a single nation } & 0 \%\end{array}$

Figure 1. Historical evolution of water conflicts. Source: (2021 authors, inspired by Geneva Water Hub (2015), with as main source: Wolf (1998).

in some arid and semi-arid regions will push between 24 and 700 million people to move (United Nations, 2020). So, in essence, all the ingredients are there for a catastrophic scenario. We can already observe this with the incessant rise in tensions around certain rivers such as the Nile, Indus, Ganges, Tigris, Euphrates, Colorado, Congo... (Islam, 1987; Warner, 2012; Abas et al., 2019; Krzymowski, 2019; Amanda, 2021). Already today several of states and social categories are competing for more than $80 \%$ of the annually available freshwater and things are only getting worse. Regions increasingly characterized by worrisome demographic trends, heightened social tensions, institutional governance failures, recurrent armed conflicts... There is no doubt that access to water could become the spark that ignites the fire.

Thus, in order to understand the precariousness of the situation, in the following sections, we are going first to demonstrate that water, as a singular re- 
source, presents characteristics that make international conflicts more likely than generic conflicts over other resources. We will then look at the consequences of climate change and global warming as multipliers of threats to the survival and security of humanity. And to better identify the water resource as a likely issue of conflicts in this twenty-first century, we will introduce successively, as an illustration and briefly, some cases of isolated water conflicts, namely: Turkish-Iraqi-Syrian, Israeli-Palestinian, Indo-Pakistani, Uzbekistan-KyrgyzstanTajikistan, Egyptian-Ethiopian, DRC-Chad and US-Mexico.

\section{Singular Characteristics of Water Resource: The Open Door to Conflicts}

Water, as a resource, presents four fundamentally political characteristics: 1) its extreme importance in the life, daily life and existence of humanity, 2) its scarcity, 3) its poor distribution and 4) the fact that it is a resource shared between different nationalities and social categories.

- Water as a sine qua non for human existence: For millennia, water has been considered, along with land and air, the most important natural resource (Butts, 1997; Chaplin, 2001; Westall \& Brack, 2018). And as scientist Albert Szent-Gyorgyi once stated, "Water is the matrix, the mother and the medium of life. There is no life without water" (Szabo, 2011). As evidence, the search for extraterrestrial life by organizations like NASA often boils down to a simple strategy: "follow the water" (Jones \& Lineweaver, 2010). It is a sine qua non of human existence because of its use in life itself [with every aspect of our lives being tied in some way to water], as well as agriculture, industry [every product produced depends on water], energy [every watt of energy produced relies on water], health [every sanitation facility depends on water] food [every morsel of food depends on water], and many other aspects of civilization.

- Water as a scarce resource: $70 \%$ of the earth's surface-the blue planet, is covered by water, which feeds the perfect illusion of an infinite resource. Because if the earth is blue, it is only on the surface. In reality, water occupies only $0.023 \%$ of the earth's mass and only $2.6 \%$ of this water is fresh. The ice caps store more than $68 \%$ of it (Oki, 2006; Shiklomanov, 1998), $30 \%$ is hidden in the water tables, the rest is quietly wandering between rivers, lakes, and other atmospheric humidity. In the end, less than $1 \%$ of the water on Earth is both fresh and liquid, or $0.007 \%$ of the land mass (U.S. Geological Survey, 2021)-a drop in the bucket in an ocean of drought.

- Unevenly distributed resource: in addition to general scarcity, the earth's fresh water is significantly maldistributed (Hoekstra et al., 2012; Ren et al., 2017). Ideally, one would like to see water where people are and equitably distributed across the globe. Unfortunately, the mapping of water resources to population distribution is often very poor, and nations' water endowments vary unfairly. The Middle East is a good example of a region facing relatively 
acute water shortages (Dolatyar \& Gray, 2000; Procházka et al., 2018). Since 1950, freshwater availability has declined by $75 \%$ and is projected to decline by another $50 \%$ by 2030 (Kandeel, 2017). This is particularly true for Iran, Iraq, and Saudi Arabia (Farzaneh et al., 2002). In addition, the populations of these three countries represent more than one-third of the total population of the Middle East. While agriculture typically uses about $70 \%$ of available water, in Iran, Iraq, and Saudi Arabia, it accounts for more than $90 \%$ of water demand (Farzaneh et al., 2002). One of the main consequences of poor water allocation is that water management, which is a highly political activity-as we shall see, becomes particularly sensitive.

- Water separating and crossing national borders and different social categories: In addition to scarcity and maldistribution, the fourth politically fundamental aspect that makes water a major stake of conflicts in this 21 st century is that it separates and crosses the national borders of more than one state and different social categories. There are currently 310 international river basins in hydrographic databases shared by 150 countries and contested areas, covering $47.1 \%$ of the earth's surface and comprising $52 \%$ of the world's population (McCracken \& Wolf, 2019). In the Middle East, the Tigris and Euphrates rivers flow through three nations [Iraq, Turkey, Syria], as does the Jordan River [Jordan, Israel, Palestine], while the Nile Basin includes 11 different countries [Ethiopia, Eritrea, Sudan, South Sudan, Egypt, Rwanda, Tanzania, Uganda, Burundi, the Democratic Republic of Congo, and Kenya]. Thus, an important distinction should be made, by way of introduction, between contiguous [international] and successive [transnational] river systems-the former referring to rivers constituting the border between two or more states, and the latter to rivers flowing through two or more states creating upstream-downstream riparian positions (Mbutamuntu \& Mimbale, 2021).

\section{Climate Change and Water Scarcity in This 21st Century}

This twenty-first century deeply marked by climate change and global warming, leads to serious consequences harmful to the survival and security of humanity [water stress ${ }^{1}$, water shortage ${ }^{2}$, aridity ${ }^{3}$, drought ${ }^{4} \ldots$.. . From the beginning of the industrial era towards the end of the eighteenth century and from the pre-industrial reference period 1850-1900 to this twenty-first century, the observation of the warming of the global average temperature of the air on the surface of the land and of the water on the surface of the oceans is really very alarming (MTEF, 2021). From 1780 to 1930, the deviation from the global average temperature is small, and then becomes mostly slightly positive until about

\footnotetext{
${ }^{1}$ An index measuring the intensity of scarcity in relation to the number of inhabitants and available resources.

${ }^{2}$ Is characterized by a higher demand than supply of water resources.

${ }^{3}$ Corresponds to the lack of precipitation on an area which can lead to its sterility.

${ }^{4}$ Phenomenon that, in addition to the lack of precipitation, is caused by human activity, often agricultural.
} 
1980. Rather, since the early 1980s, global temperature warming has been steadily increasing, with a continued growth in the decadal mean (MTEF, 2021). The 2010-2019 decade [with a temperature $0.66^{\circ} \mathrm{C}$ above the $1961-1990$ average] was $0.19^{\circ} \mathrm{C}$ warmer than the $2000-2009$ decade $\left[0.47^{\circ} \mathrm{C}\right.$ above the $1961-1990$ average] (MTEF, 2021; WMO, 2021). The last five years since the beginning of this twenty-first century [i.e., 2020, 2019, 2018, 2017, and 2016] are the five warmest years observed since the beginning of the industrial era and the pre-industrial reference period 1850-1900 (MTEF, 2021; WMO, 2021). The year 2016, with a temperature $0.86^{\circ} \mathrm{C}$ above the $1961-1990$ average, ranks as the warmest year since 1850, with the years 2020 and 2019 ranking successively second and third (WMO, 2021). Since the pre-industrial reference era 1850-1900, the global average temperature has increased by almost $1^{\circ} \mathrm{C}$ [2010-2019 decadal average of $0.97^{\circ} \mathrm{C}$. According to the United Nations Framework Convention on Climate Change (UNFCCC), with reference to World Meteorological Organization (WMO) data, there is a 40 percent probability that the global annual average temperature will temporarily reach $1.5^{\circ} \mathrm{C}$ for at least one of the next five years, and this probability may well increase over time (UNFCCC, 2021; Makengo, 2020). And many experts continue to warn that if humanity continues on its current trajectory of carbon dioxide emissions, global temperature levels could well rise by 3 to 5 degrees Celsius by the end of the twenty-first century.

In fact, the adverse effects of this continuous climate change are indeed plural, they are manifested through several aspects of globe geography, but they are more pronounced on water resources. According to the World Bank (2021), nine out of ten natural disasters are water-related. And water-related climate risks cascade through food, energy, urban, and environmental systems... We also find with Schleussner et al. (2016) in looking at data on armed conflict outbreaks and climate-related natural disasters for the period 1980-2010, that the link between climate disasters and conflict was particularly strong in ethnically divided countries, and was stronger for droughts and heat waves than for floods. More recently, Grasso (2021) observes that the frequency of hydrological hazards has increased over the past 20 years. Since 2000, the number of flood-related disasters has increased by $134 \%$ over the previous two decades, including in Asia-about 130, and in Africa-about 277, from 1970 to 2019 (Grasso, 2021). The number and duration of droughts also increased by $29 \%$ over the same period-with most drought-related deaths occurring in Africa-about 695,081 from 1970 to 2019 (Grasso, 2021).

In talking about the effects of climate change on water scarcity that is hitting the planet in this twenty-first century as a natural physical phenomenon, we must not, however, obscure the human responsibility in accentuating such environmental degradation. Beyond the greenhouse gases that come from human activities include for example the burning of carbon, oil and gas, deforestation, agriculture and household. It is also worth noting here the negative externalities of hydropower. Indeed, as countries around the world strive to wean themselves off fossil fuels and to the nuclear energies, hydropower is seen as a more envi- 
ronmentally friendly alternative. The problem with "hydroelectric dam" is that it significantly disrupts the course of rivers and severely damage ecosystems. This is the case of the Mekong River in Southeast Asia, which is now a shadow of its former self due to the numerous hydroelectric dams built in recent years along a large part of its course, from China to Cambodia (Cross, 2021). In addition, there are now 60,000 large dams in the world, of which more than 3700 are currently planned or under construction-mostly on 260,000 kilometers of rivers, from the Amazon in South America to the Congo in Africa and the Irrawaddy in Asia. And we should not underestimate the impact that these works have on environmental degradation but also in the amplification of disputes between states and different social categories to the competing uses of water resources-as we will see later in this paper. In Africa, for example, many countries, such as Zambia, are turning to hydropower to meet their growing energy needs. But researchers warn that some of the planned projects are fundamentally misguided. There are concerns that a proposed dam on the Luangwa River in Zambia-one of the longest free-flowing rivers in southern Africa, will struggle to function due to seasonal fluctuations in the river (The National Geographic, 2021).

\section{The Increasing Threats to Human Survival and Security}

The effects of climate change, combined with the negative externalities of both energy and non-energy water policies and activities logically make water scarcity in the twenty-first century a multiplier of threats to human survival and security. This neo-Malthusian thesis of "threat multiplier" (Benjaminsen et al., 2012) in reference to contemporary environmental disturbances, often referred to as "climate change", considers that the increase in the power and frequency of sudden climatic events, coupled with the increase in the world's population and the scarcity of water resources, is likely to negatively affect human survival and security, stimulating furthermore armed conflicts (Bou Nader, 2018). In this way, climate change-viewed in its entirety, acts as a "threat multiplier" by exacerbating other risks to the security and survival of humanity. However, this exacerbation involves, progressively, three levels of impact manifestations on human survival and security:

- Direct Impacts: These mainly affect the income sources of the affected populations. These losses can cause a rural exodus that will undermine the infrastructure of the host cities. If the relevant state apparatus is not resilient enough, many diseases and epidemics may develop due to the failure of public services such as hospitals and health services. Akwagyiram (2018) reports, for example, that violence in Nigeria between sedentary farmers and cattle herders-who move seasonally to find pasture, has killed six times as many people [more than 1300 deaths between January and June 2018] as the terrorist group Boko Haram in the first half of 2018. For International Crisis Group, the roots of the conflict lie in part "in climate-induced pasture degradation" (International Crisis Group, 2018). As drought and desertification have dried up springs and streams in the far north of Nigeria's Sahelian belt, 
large numbers of pastoralists have been forced to seek alternative pastures and water sources for their livestock. And in a context deeply marked by the struggle for survival due to such aridity, it is difficult for them to act other than by violence.

Delayed Impacts: These arise from direct impacts and the failure or inability of the state to deal with direct impacts. These impacts can take the form of massive emigration, sporadic or prolonged armed conflicts due to the grievances of the populations concerned, often members of ethnic or religious minorities; loss of legitimacy of the state, driving other grievances that will be expressed through armed violence, etc. Some researchers go so far as to establish a link between climate change and its delayed impacts on armed conflict in Syria, Afghanistan (Anon, 2019) or even Nigeria-even to the rise of the Islamic State. Hammer (2013) considers, for example, that the destabilization of Syria can be explained in part by the delayed impacts of climate change. A context where you have 1) a devastating drought situation, started in 2006, which forced many farmers to abandon their fields and migrate to urban centers; 2) the consequence of a massive displacement of populations fleeing aridity, integrating new agglomerations, accelerating by ricochet the rate of unemployment, and favoring in fact, the conditions for a revolution. Finally, consider the poor agricultural conditions of the host region, which fostered the early recruitment efforts of the Islamic State (The National Geographic, 2017). Of course, when people lack food and water-exacerbated by prolonged droughts, water scarcity, they seek to satisfy their immediate human needs by fleeing to terrorists or migrating to perceived safety. In this way, climate risks multiply the other threats we already face.

- Vacuum Impacts: The result will be a set of voids-such as brain drain from the country; strategic penetration by other riparian countries that will take advantage of conflicts or intervene in order to stabilize their borders with the affected country; partition of the country; etc. (Bou Nader, 2018).

Thus, these threats seen by combining the four singular characteristics of water pinpointed above [a resource that guarantees our existence, a scarce resource, an unevenly distributed resource, a resource shared between several States and social categories], to the heavy consequences of climate change and to the hydrid policies and activities of various actors at stake, emerges an exceptional implication: the great need for cooperation between riparian states, nationalities and various social categories, and the great likelihood of conflicts between them-to the competing uses of the shared water resource and to each other's conquering spirits. This paper, however, observes of the predominant tendency of the second implication-the conflictual one-over the first-the cooperative onein this twenty-first century, which clearly indicates that the management of shared water resources should be taken seriously as a major conflict issue of our century. To see this, imagine that your water supply was no longer meeting your needs-that you were getting less and less water every year, and that supply trends were showing alarming proportions in the sense that your survival was at 
risk. Then imagine that your neighbor-a riparian state of your watershed, was living in complete ignorance of your situation by showing a disobliging hydro-hegemonic attitude and use of shared water resources for purposes other than navigation [e.g. the policy of large hydroelectric dams and artificial canals]... And if one observes, at the same time, that other states of the watercourse are also going through the same situation of water resource scarcity. We can deduce that, for most of these riparian states, water conflicts are an existential issue in the short term, for several reasons mentioned above: shortage of fresh water, food shortages, energy shortages... But in any case, some rivers are considered more at risk than others, the case of the Tigris and the Euphrates, the Jordan, the Indian, the Syr Darya, the Nile, the Congo and Chad, the Colorado and the Rio Grande. We can see that the most affected states are mainly in the Middle East and North Africa, in Central and South Asia, but also in America. It should also be noted that the situation of these watersheds is all the more worrying when we take into account the singular characteristics of these regions where you have: 1) a rapidly growing demography, 2) social tensions exacerbated by chaotic political governance, 3) institutional governance flaws, 4) recurrent armed conflicts... We might as well recognize that in such a context, access to water could well become the spark that sets the powder keg on fire. In the following lines, we propose to show that by outlining successively a few cases of bellicose rhetoric between riparian states-the Turkish-Iraqi-Syrian, Israeli-Palestinian, Indo-Pakistani, Uzbekistan-Kyrgyzstan-Tajikistan, Egyptian-Ethiopian, DRC-Chad and US-Mexico cases.

\section{The Turkish-Iraqi-Syrian Case}

The Tigris [1899 km long] and Euphrates [2700 km long] rivers that flow through Iraq and Syria have their source in Turkey in the watered mountains of eastern Anatolia. For Ankara, the control of these rivers is a considerable geopolitical stake for stability in the Middle East (Al-Ansari, 2019). As an upstream country, it holds the key to the tap that flows to Syria and Iraq. In the absence of genuine regional cooperation, Turkey is often accused of being a hydro-hegemon and its development strategy initiated under the Great Anatolian project (Bazin \& De Tapia, 2015) - a program launched in 1970 that aims to erect 22 hydroelectric dams on the Tigris and Euphrates rivers, threatens the survival of Syria and Iraq. In 2018, riots had broken out in Basra (Iraq) following the water shortage caused by the filling of the Ilısu dam on the Tigris and which, in terms of impact, led to the cessation of corn, rice and grain crops in Iraq. The herds had also decreased by $30 \%$ compared to 2017 (Chesnot, 2019). And so, very clearly, the downstream countries are not taken into consideration at all. Also, Ankara's strategy is all the more problematic since its hydroelectric development projects on the upper reaches of the two rivers cause the loss of $50 \%$ of the natural flow of the Tigris and 70\% of that of the Euphrates (Daoudy, 2006). If we combine, moreover, the total water demand of Turkey, Syria and Iraq which 
amounts to $107 \%$ of the potential of the title and $147 \%$ of the potential of the Euphrates (Yalchin, 2011), the situation appears more delicate. Attempts at negotiation to ensure a better sharing lead to deadlocks-so much so that the relations between the three riparians regarding the management of water resources give rise to as many twists and turns [1974 with a confrontation between Syria and Iraq narrowly avoided thanks to the mediation of Saudi Arabia], to questioning [1990 concerning the non-compliance of Turkey with its commitments], and to crisis $[1990,1993 \ldots]$. In short, it is a real race against time. Of course, Syria is one of the driest countries in the world, but on top of that, from 2006 to 2011 , the country experienced a major drought. $75 \%$ of farms go bankrupt, $85 \%$ of livestock die, 1.5 million farmers and agriculturists move to the cities to find work (Kelley et al., 2015). When we add the deterioration of the economy, social instability, the emergence of Islamist groups... we might as well recognize that water can, in such a context, prove to be a major stake of conflict between riparian states.

\section{The Israeli-Palestinian Case}

Between Israel and Palestine, the hydraulic situation adds another layer to the geopolitical complexity of the already existing conflict. A conflict that could only be seen from an ethnic-religious point of view (Sela \& Yakira, 2003)-that of the confrontation of Jewish and Arab-Muslim civilizations (Boniface, 2004)-and then that of the Palestinian struggle for self-determination in the face of Jewish domination (Rodman, 2019)... However, one of the fundamental aspects too often overlooked in Israeli-Palestinian hostilities is that of access to the Jordan River. Indeed, since its accreditation as a sovereign nation-state, Israel has considered water supply as a key political lever. This position is justified by the scarcity of the resource in this region where water stress is omnipresent. If the Six Day War broke out in 1967, it was at least partly because of this issue (Seliktar, 2005). Let us recall that this war began the day Israel decided to intervene against the detour of the Jordan River. Following this intervention, the confrontation between Israel and Palestine was inevitable. But this war allowed Israel to conquer new territories rich in water resources, such as the Golan Heights and the West Bank (Harris, 1978). And so in many ways, Israeli-Palestinian rivalries are inseparable from the struggle for the "blue gold". For the Palestinians, Israeli control over water management is so restrictive that it prevents the improvement of their living conditions. Israel, on the other hand, considers control of the Jordan River to be a sine qua non for its existence as a state. Imagine for a moment if these waters fell under the control of Islamic powers and they held the key to the tap to Israel, and all this in a context marked by the refusal to recognize Israel as a nation... And so basically, the threat has always been existential. On the other hand, the fact that the Jordan River is under Israel's authority gives the latter major political leverage for the geopolitical stability of the region. From this perspective, it is difficult to imagine Israel conceding any form of wa- 
ter independence to Palestine. The water relations between the two riparians seem, in fact, deadlocked and combined with our century deeply marked by the drying up of water resources, all the ingredients are gathered for a catastrophic end if nothing is done.

\section{The Indo-Pakistani Case}

The Indo-Pakistani case is one of the most active contemporary rivalries. The two littoral states are suspicious and hostile towards each other. Among the most contentious issues between the two countries is the control of Kashmir [located between northern India, northeastern Pakistan and extreme southwestern China] and more specifically the Indus River [3180 km long], one of the most powerful rivers in Asia. To understand how this came about, one must go back more than 70 years to the partition of India in 1947 (Schmidt, 2015). Indeed, after the partition of India in 1947 by the United Kingdom, Pakistan lost control over the source of the river which comes under the authority of India. The problem is that Pakistan's irrigation system-absolutely necessary for its agriculture, is entirely dependent on the Indus. The threat is obvious. The two major countries in the basin divided the rights to the various tributaries under the Indus Water Treaty of 1960 (Abas et al., 2019; Biswas, 1992). This agreement survived various wars and other hostilities between the two countries, and as such, it is widely considered a success. Today, however, the treaty is hanging by a thread as it faces challenges far beyond the scope of the agreement. It must be said that every time there is a conflict between the two riparian states, one or the other threatens to sabotage the water management system. The danger of a new conflict is all the greater now that India and Pakistan possess nuclear weapons and still refuse to sign the 1970 Nuclear Non-Proliferation Treaty. The temptation remains strong. And any conflict between two nuclear-armed enemies could easily spread far beyond their own borders-hence the need to consider water scarcity, wherever it occurs, as everyone's business. As far back as February 4, 2019, the World Bank was concerned about the difficulties Pakistanis face in getting water. On August 5, 2019, New Delhi decided to abolish the autonomous status that Kashmir had enjoyed until then (Delacroix, 2019). With this act, India has clearly challenged the geopolitical balance of the water system between itself and its neighbor, Pakistan, and consequently exacerbated the political animosity that already existed over Kashmir. But if the two countries were to engage in an armed conflict over the Indus River, there is a strong likelihood that it would lead to an almost unprecedented humanitarian crisis.

\section{The Uzbekistan-Kyrgyzstan-Tajikistan Case}

The countries of Central Asia-Uzbekistan-Kyrgyzstan-Tajikistan, are in the midst of growing tensions with control over water resources at stake (Krutov \& Spoor, 2003; Xenarios et al., 2018). To understand this situation, we need to go back to Soviet history, where the somewhat presumptuous idea that nature could 
be tamed by technology, machines and concrete emerged. So they built a huge irrigation network-turning the steppe into fertile land-including $32,000 \mathrm{~km}$ of canals, 45 dams, and more than 80 reservoirs, all of which were intended to irrigate vast fields of cotton and wheat in Kazakhstan and Uzbekistan (Erdinger et al., 2019; The National Geographic, 2019)... Secondly, one should consider the fact that this region, which was once one of the commercial and cultural crossroads of the Silk Road-at the crossroads of the European and Asian continents, the policies carried out during the time of the USSR and the territorial divisions that followed have placed these states in a spiral of recurrent, even permanent, tensions. A Soviet territorial division carried out deliberately with the aim, obviously, of preventing the emergence of a single power and maintaining Russian tutelage over the region. After their independence, these states have all had the reflex to demonstrate their existence as an autonomous entity by administering in a sovereign manner the water resources flowing on their respective territories [the principle of absolute sovereignty]. And in a context where each one asserted a sovereign right over its territory, we were undoubtedly entering a phase of withdrawal, of reorganization, of constitution of States, of societies capable of developing their own discourse and formulating their own specific policies on water. This logically makes the three protagonists losers in this game, which, by the way, is not even a zero-sum game [where each has more than the other] but rather a negative-sum game where everyone loses [lose-lose situation].

Today, with climate change, global warming, their direct consequences on water resources, and the territorial demarcations wanted by the Soviet Union ... force these states to change their attitude by focusing more on the management of the resource upstream of the watershed. But it is especially in the Ferghana Valley where the Syr Darya River flows [2500 km long] that the efforts of a fragmentation by the USSR are the most apparent (Anon, 2015). The valley is inhabited by 14 million people. The main economic activity is agriculture, especially cotton cultivation - and each of the riparian states needs fresh water for irrigation (Heathershaw, 2010). However, a look at the territorial geopolitics of the region shows that goodwill is elusive at best. The valley, which forms a clear geographical unit, is nevertheless divided into three enclaves. In fact, tensions are frequent. The ethnic groups scattered in the three countries live in constant fear. Clashes are recurrent and often extremely violent. And among the list of important issues that constantly recur is the question of water sharing. Each riparian state contests the water management of the other riparian state in a region already facing a worrying water shortage. Finally, the valley is now one of the most contested regions in the world (Nunan, 2013). And as such, there is no reference to a short or medium term horizon, the water wars are already underway.

\section{The Egyptian-Ethiopian Case}

The issue of Egypt and Ethiopia case has similarities to that of Turkey, Iraq and 
Syria case. For hundreds of years Egypt, a downstream country, considered the Nile as its exclusive property. Its entire civilization developed around the Nile (Moret, 2013). For Egypt, the Nile is of paramount importance not only from a political and economic point of view, but also from a cultural and historical point of view. The problem is that there are ten other states that are located directly in the Nile watershed and do not take full advantage of the opportunities offered by the great river. Since the beginning of the 20th century, they have been pushing for a paradigm shift in the management of the Nile. At the beginning, it was mainly Sudan that took care of it. But more recently, it is Ethiopia that takes over. After years of misery, Ethiopia is experiencing an average economic growth of $10 \%$ (International Monetary Fund, 2018), coupled with a population growth of $24.8 \%$ per year (INED, 2021) and an urbanization of its population. There is one infrastructure project in particular that embodies the progress of the Ethiopian people: The Renaissance Dam. This dam, more than a symbolism of Ethiopian influence, is above all a vital development project for the country. It is also part of a desire to ensure not only the growing energy needs of its population, which is increasing by $30 \%$ per year, but also its food needs since the water from the dam will also be used for irrigation. The challenge is that it is located on the Blue Nile-the tributary of the Nile that provides $70 \%$ of its flow (Conway, 2000). Suddenly, Egypt's freshwater supply is directly threatened. At this stage, it cannot be said that Ethiopia's development strategies are fundamentally altering the course of the Nile, but it is very clear that if trends are extended, Ethiopia's position portends higher withdrawals from the Nile upstream of Egypt, and potentially overexploitation. Yet Egypt is experiencing rapid population growth. From 94 million in 2015, it is expected to reach 153 million in 2050 (Goldstone, 2019). Proportionally to the increase in its demography, its water needs are continuously increasing while they are already estimated at 73 billion $\mathrm{m} 3$ per year, nearly 20 billion more than their theoretical share of the Nile water. And if we consider today that Egypt would be facing an alarming water supply situation-down to an average of 660 cubic meters per person in 2013, compared to more than 2500 cubic meters in 1947 (The Guardian, 2015) and that at the same time, we see on the horizon, upstream of the Nile watershed, the Ethiopian Renaissance Dam project is looming, and some studies show that the structure could result in a $25 \%$ drop in the flow of the Nile in Egypt, so there is cause for concern about how this situation may end. In the meantime, Egypt is fuming, Ethiopia is threatening, and the current configuration does not augur well.

\section{The DRC-Chad Case}

First, the issue at stake in the DRC-Chad case is fundamentally different from all the cases of bellicose rhetoric presented in this paper. It raises three particularities:

- The first is that the water conflict between the two main protagonists does not relate to a shared watershed but rather to two distinct watersheds-the 
Lake Chad basin and the Congo basin.

- The second is that this water conflict is not reduced to the two leading states but rather to a very wide range of actors-systematically opposing the states of the LCBC [Chad, Nigeria, Cameroon, Niger, Algeria, Central African Republic, Libya and Sudan] to those of the CICOS [Congo-Brazzaville, Congo-Kinshasa, Cameroon, Central African Republic, Gabon, and Angola].

- The third is that the water dispute here does not refer to upstream-downstream riparian positioning benefits, but rather to the interbasin water transfer project, the Transaqua project- “Trans" for transport and "Aqua" for water, in Latin-Italian, drafted in the late 1970s and introduced into political agendas in the 1980s by an Italian engineering firm, Bonifica (Adeniran \& Daniell, 2021; Mimbale, 2021).

Secondly, and according to Bonifica's original 1970 project proposal, Transaqua envisages the construction of a large navigable canal of $2400 \mathrm{~km}$ between the Congo River and Lake Chad, which would transfer 100 billion cubic meters of water per year-about $5 \%$ of the annual flow of the Congo River-to Lake Chad. It therefore aims to link the Congo Basin to other African countries and to two seaports [Mombasa and Lagos] by a navigable canal [transport and trade networks] (see Figure 2). It also plans to build a series of hydroelectric stations

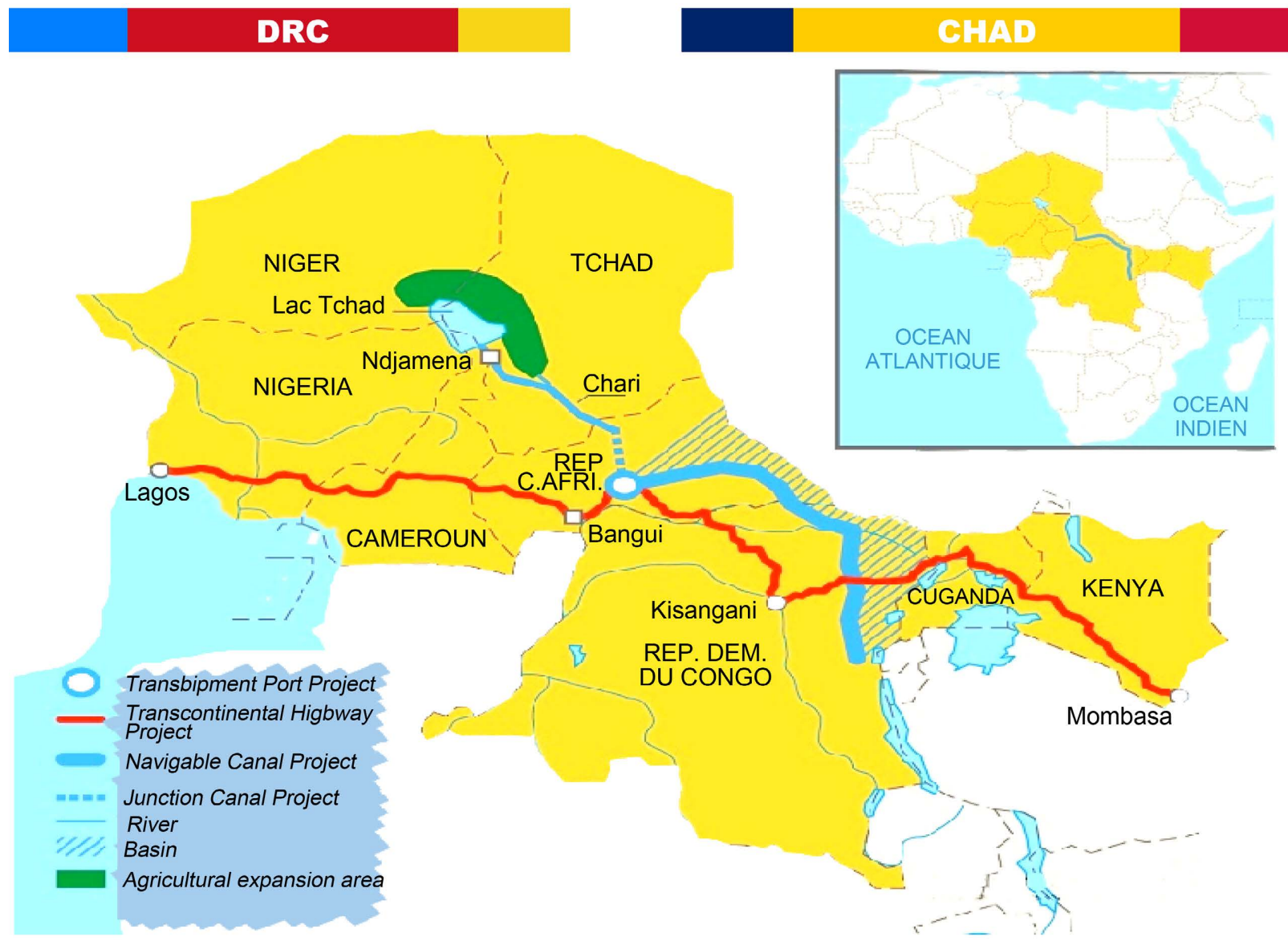

Figure 2. Transaqua project. (02021 authors, inspired by Schiller Institute (Acheikh, 2015). 
along the canal to generate 30 to 35 billion $\mathrm{kWh}$ of power. The project also expects to create 50,000 to 70,000 km of irrigated area in the Sahel (Bonifica, 1982, 1984, 1985). It is in fact presented as an opportunity for the Sahel region and the Congo Basin in the sense that Transaqua would consider strengthening the food and energy security of the region. However, the proposal did not materialize due to several factors [the cost of the project, socio-political instability in the region; opposition from the Congolese side (DRC); the Inga III project; environmental, community and cultural perspectives].

Thirdly, in 2000, the LCBC took the initiative and stressed the need for an inter-basin water transfer project and requested a feasibility study. CIMA International undertook to carry out a pre-feasibility study. The study resulted in a second proposal for an Interbasin Water Transfer project which consists of the construction of two dams on the Kotto and Oubangui tributaries of the Congo River, likely to result in the transfer of 6.4 billion $\cdot \mathrm{m}^{3}$ of water to Lake Chad from the reservoirs produced by these proposed dams. This water would flow from the Ubangi to the Chari River [the main tributary of Lake Chad] via a $1350 \mathrm{~km}$ navigable channel (CIMA International, 2011).

Then in 2018, the first Interbasin Water Transfer proposal, the Transaqua project, was approved by the LCBC states as a preferred means of revitalizing Lake Chad (International Conference on Lake Chad, 2018; Italian Republic, 2018). And there is currently a notable development in the implementation of the project through, in particular, the signing of a memorandum of understanding between the LCBC and PowerChina. Recall also that in 2017, an agreement was reached between Bonifica and PowerChina to jointly conduct the feasibility studies; and in 2018, at the Abuja conference, a roadmap was approved by the LCBC Heads of State, describing the Water Transfer project as "a necessity, not an option".

Given this development, Transaqua is likely to be seen as a one-sided initiative with a derogatory attitude that irritates and annoys the Congo and its people. Some researchers have even evoked conspiracy theories against Transaqua (Amani Ntale, 2021; Musavuli, 2018). For how can one think about the transfer of Congo's waters without the Congolese themselves? And this is where the Bambara wisdom makes sense: "you don't shave someone's head in their absence". And very recently we have witnessed a media uproar, a war of words without equal between these two groups of protagonists. We remember Idriss Deby's shocking exit in 2016 arguing - we quote: "we will take the waters of the Congo River by choice or by force" (Kongo, 2021). This media release caused an uproar on the Congolese side and reactions came from all over the country through the media, civil society, citizen movements, NGOs in charge of water, parliament, etc. One could read comments such as "the water war at DRC's gates" (Bekanga, 2018), "the Congo on the verge of its third genocide-the genocide of water" (Musavuli, 2018), "after the plundering of minerals, soon the plundering of DRC's fresh water” (Tshibwabwa, 2017)... In short, this problem 
raises several concerns and for the time being, it is far from being solved as national interests diverge and the concerns of both sides do not really fit into a social co-construction perspective of the initiatives and their leaders.

\section{The US-Mexico Case}

The United States-Mexico case has been in a state of ankylosis for some time, which is less worrisome for the moment. After the controversies surrounding the dividing wall between the two countries (Demata, 2017), the issue of sharing water from the Colorado and the Rio Grande-known as the rio Bravo del Norte in Mexico, is amplifying the tensions between the two riparians (Figure 3).

The Colorado River, a state in the United States $\left[260,837 \mathrm{~km}^{2}\right]$, also refers to a river originating in the Rocky Mountains of the state of Colorado-more precisely in the Rocky Mountains National Park, crossing 5 American states [Colorado, Utah, Arizona, Nevada and California], providing drinking water to more than 40 million people, stretching for $2334 \mathrm{~km}$ before ending its course in Mexico and flowing into the sea (Butler et al., 2021). The Rio Grande, longer than the Colorado River, it forms the entire border between Texas and Mexico, half of the only land border between the South and the North [2000 km from El Paso to the Gulf of Mexico] (Lavariega Monforti \& Graham, 2018).

Basically, the cooperation between the two countries regarding the sharing of these two rivers is old-with treaties dating back to 1906 and 1944 (Mumme, 2020). For several decades, all was well until drought due to climate change (Anon, 2010; Warren, n.d.; Woodhouse \& Pederson, 2018) and the overexploitation of said rivers [man-made lakes, gigantic dams, and diversion canals] (Anon, 2020; Bohn et al., 2018) fueled tensions between riparians. Recall that Colorado has been plagued by drought for nearly 20 years (Mokry, 2021). And in the seven states through which it flows, the river is diverted by human hands and drawn, sometimes to excess. Its water feeds intensive agricultural fields [alfalfa, cotton, cattle], some of which are located in the middle of the desert... As a result, the Colorado is dried up before it even crosses the border. On the other side, the Rio Grande is dry and in danger of drying up permanently (Fleming, 2021; McFadden, 2020). The problem is that once Mexico is no longer able to supply the United States with a certain amount of water via the Rio Grande, Washington
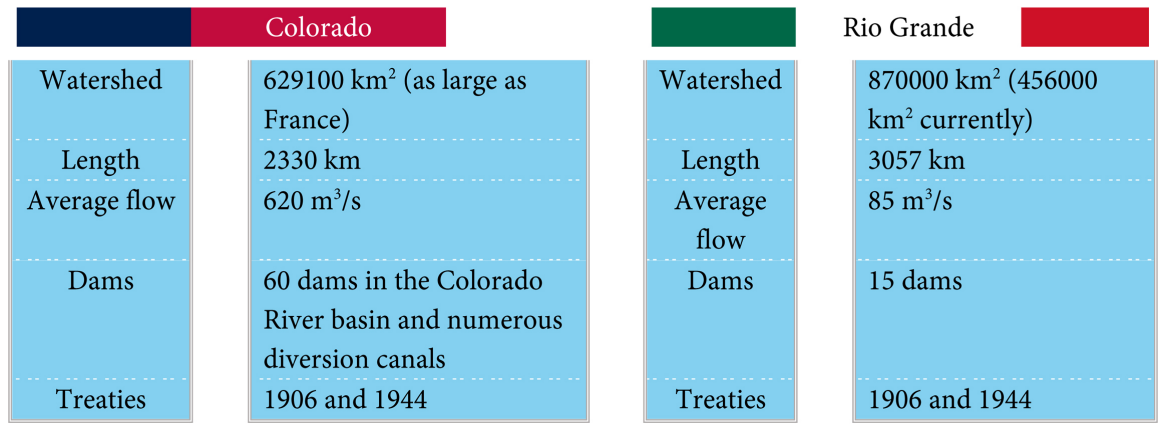

Figure 3. Comparative panel between the Colorado and Rio Grande rivers. (C2021 authors, inspired by Descroix (2011). 
feels compelled to close the Colorado River.

Of course, the relationship between the two countries in terms of water governance is somewhat complex. But to understand this complexity, one must go back to the bilateral agreements of 1906 and 1944. These treaties provide for the amount of water that the United States owes to Mexico and vice versa. They also include flexibility instruments, with the possibility for the United States to reduce deliveries in the event of drought, and a five-year cycle, which allows Mexico to organize deliveries according to the country's capacities, evaluated annually. However, Mexico has often been, apart from the current drought condition, beyond the deadlines (IAGF, 2020). These repeated delays have added fuel to the fire in relations with the United States. Also, the situation is probably not perceived as such by the population. As evidence of this, in October 2020, farmers had taken control of the Boquilla Dam (Constable, 2020), located on the Conchos River, a major tributary of the Rio Grande-an occupation that aimed to prevent the delivery of water owed by Mexico to the United States, as required by treaties. It is true that despite these tensions, the two states have demonstrated their ability to cooperate. But it is all down to the wire-as long as the drought continues and lasting solutions are not found.

\section{Conclusion}

This study has shown the existence and the risk of conflicts related to access and management of water which put and will put to a great test the peaceful coexistence between the States and various social categories. By using a few cases of bellicose rhetoric on the Tigris-Euphrates, Jordan, Indus, Syr-Daria, Nile, Congo, Colorado and Rio Grande watersheds, the results we have reached clearly demonstrate that water should be taken seriously as a major stake of conflicts in this 21 st century. The multiplication of threats arising from climate change, which continues to worsen in this century, coupled with the hybrid policies and activities of various actors at stake, and combined with the singular characteristics of water-including, notably, a resource that guarantees our existence, a scarce resource, an unevenly distributed resource, and a resource that is shared among several states, emerge two fundamental implications: 1): the great need for cooperation between riparian states, nationalities and various social categories, and 2) the great likelihood of conflicts between them-to the competing uses of the shared water resource and the conquering spirits of one another. Through some cases explored in this paper, we have come out of a bitter observation of the predominant tendency of the second implication-the conflictual one-over the first-the cooperative one-in this twenty-first century. Thus, this paper considers that it is important and time for humanity to promote transboundary water cooperation between states and nationalities of shared river basins; and integrated water management in the steps of good governance at all levels, in the sense of avoiding a flare-up of the situation and limiting to the maximum a worsening where the violins do not agree anymore. These perspectives, 
whose milestones have been set, constitute an avenue of research that deserves to be explored further.

\section{Conflicts of Interest}

The authors declare no conflicts of interest regarding the publication of this paper.

\section{References}

Abas, N., Khan, N., Saleem, M. S. et al. (2019). Indus Water Treaty in the Doldrums Due to Water-Power Nexus. European Journal for Security Research, 4, 201-242. https://doi.org/10.1007/s41125-019-00043-y

Acheikh, I.-O. (2015). Réalimenter en eau le lac Tchad, un grand projet pour les BRICS. https://www.institutschiller.org/Realimenter-en-eau-le-lac-Tchad-un.html

Adeniran, A. B., \& Daniell, K. A. (2021). Transaqua: Power, Political Change and the Transnational Politics of a Water Megaproject. International Journal of Water Resources Development, 37, 234-255. https://doi.org/10.1080/07900627.2020.1747408

Akwagyiram, A. (2018). Nigeria Grazing Violence Kills Many More than Boko Haram, Poses Serious Stability Threat-Think-Tank. https://www.reuters.com/article/uk-nigeria-security-idUKKBN1KG03X

Al-Ansari, N. (2019). Hydro Geopolitics of the Tigris and Euphrates. In Y. Mustafa, S. Sadkhan, S. Zebari, \& K. Jacksi (Eds.), Recent Researches in Earth and Environmental Sciences Part of the Springer Proceedings in Earth and Environmental Sciences Book Series (SPEES) (pp. 35-70). Springer. https://doi.org/10.1007/978-3-030-18641-8_4

Amanda, L. (2021). New Water Wars Are Coming to the American West. https://www.columbian.com/news/2021/jul/01/little-new-water-wars-are-coming-to-th e-american-west

Amani Ntale, D. (2021). Le projet Transaqua, un danger pour la nation congolaise. https://laprunellerdc.info/tribune-le-projet-transaqua-un-danger-pour-la-nation-cong olaise

Anon (2010). Global Climate Change Impacts in the United States. Choice Reviews Online, 47, 47-4432. https://doi.org/10.5860/CHOICE.47-4432

Anon (2015). Increasing Human Security to Avert Water Wars in the Ferghana Valley. In Environmental Crises in Central Asia (pp. 45-56). Routledge. https://doi.org/10.4324/9781315824840-12

Anon (2019). Climate Change as a Driver of Conflict in Afghanistan and Other Fragile and Conflict Affected States/Roz Price. Afghanistan Centre at Kabul University. https://doi.org/10.29171/azu_acku_pamphlet_ge320_a33_p753_2019

Anon (2020). Challenges and Issues in the Management of Groundwater: The Case of the US-Mexico Border Region. In M. M. Murcia (Ed.), International Groundwater Law and the US-Mexico Border Region (pp. 36-58). Brill.

https://doi.org/10.1163/9789004385085_004

Ayeb, H. (1998). L'eau Au Proche-Orient: La Guerre n'aura Pas Lieu. Khartala.

Bazin, M., \& De Tapia, S. (2015). Le Projet de l'Anatolie du Sud-Est (GAP) dans son contexte national turc et régional moyen-oriental. Bulletin de l'Association de géographes français, 92, 184-207. https://doi.org/10.4000/bagf.596

Bekanga, K. (2018). La guerre de l'eau aux portes de la RDC. https://kasaidirect.net/wordpress/?p=10107 
Benjaminsen, T. A., Alinon, K., Buhaug, H. et al. (2012). Does Climate Change Drive Land-Use Conflicts in the Sahel? Journal of Peace Research, 49, 97-111. https://doi.org/10.1177/0022343311427343

Bernauer, T., Bohmelt, T., \& Koubi, V. (2012). Environmental Changes and Violent Conflict. Environmental Research Letters, 7, Article ID: 015601. https://doi.org/10.1088/1748-9326/7/1/015601

Biswas, A. K. (1992). Indus Water Treaty: The Negotiating Process. Water International, 17, 201-209. https://doi.org/10.1080/02508069208686140

Bohn, T. J., Vivoni, E. R., Mascaro, G. et al. (2018). Land and Water Use Changes in the US-Mexico Border Region, 1992-2011. Environmental Research Letters, 13, Article ID: 114005. https://doi.org/10.1088/1748-9326/aae53e

Boniface, P. (2004). Le choc des civilisations et le conflit israélo-palestinien. Revue internationale et stratégique, 53, 11. https://doi.org/10.3917/ris.053.0011

Bonifica (1982). Transaqua: An Idea for the Sahel. Executive Intelligence Review, 24, 7-19.

https://larouchepub.com/eiw/public/1997/eirv24n35-19970829/eirv24n35-19970829_0

07-transaqua_an_idea_for_the_sahel.pdf

Bonifica (1984). “Transaqua” Zaïre. Rome.

Bonifica (1985). “Transaqua” Central African. Rome.

Bou Nader, P. (2018). Le changement climatique comme multiplicateur de conflits armés. Les Champs de Mars, No. 30, 449. https://doi.org/10.3917/lcdm.030.0449

Butler, A., Fulp, T., Prairie, J. et al. (2021). Water Resources Management in the Colorado River Basin. In Handbook of Catchment Management 2e (pp. 441-463). Wiley. https://doi.org/10.1002/9781119531241.ch18

Butts, K. H. (1997). The Strategic Importance of Water. The US Army War College Quarterly: Parameters, 27, 65-83.

https://press.armywarcollege.edu/cgi/viewcontent.cgi?article $=1809 \&$ context=paramete rs

Chaplin, M. (2001). Water: Its Importance to Life. Biochemistry and Molecular Biology Education, 29, 54-59. https://doi.org/10.1016/S1470-8175(01)00017-0

Chesnot, C. (2019). La bataille de l'eau entre la Turquie et l'Irak. https://www.franceculture.fr/geopolitique/la-bataille-de-leau-entre-la-turquie-et-lirak

CIMA International (2011). Feasibility Study of the Water Transfer Project from the Ubangi to Lake Chad Summary Document: Main Results of the Feasibility Study. Summary Report No. 30 .

http://savelakechad.com/maps--info/cima-lcbc_final_summary_rep.pdf

Constable, P. (2020). Mexican Farmers Occupy Dam to Stop Water Payments to the United States.

https://www.washingtonpost.com/world/the_americas/us-mexico-water-dam-farm-pro test/2020/09/13/dddb85e8-f3bb-11ea-999c-67ff7bf6a9d2_story.html

Conway, D. (2000). The Climate and Hydrology of the Upper Blue Nile River. The Geographical Journal, 166, 49-62. https://doi.org/10.1111/j.1475-4959.2000.tb00006.x

Cross, D. T. (2021). Planned New Hydroelectric Dams Threaten Mighty Rivers Worldwide.

https://www.sustainability-times.com/low-carbon-energy/planned-new-hydroelectricdams-threaten-mighty-rivers-worldwide

Daoudy, M. (2006). Une négociation en eaux troubles ou comment obtenir un accord en situation d'asymétrie. Négociations, 6, 65. https://doi.org/10.3917/neg.006.81 
De Stefano, L., Edwards, P., de Silva, L., \& Wolf, A. T. (2010). Tracking Cooperation and Conflict in International Basins: Historic and Recent Trends. Water Policy, 12, 871-884. https://doi.org/10.2166/wp.2010.137

Delacroix, G. (2019). Au Cachemire, l'Indus coule au milieu des tensions. https://www.lemonde.fr/m-le-mag/article/2019/08/16/au-cachemire-l-indus-coule-aumilieu-des-tensions_5500028_4500055.html

Demata, M. (2017). A Great and Beautiful Wall. Journal of Language Aggression and Conflict, 5, 274-294. https://doi.org/10.1075/jlac.5.2.06dem

Descroix, L. (2011). Des conflits de l'eau à la limite du Nord et du Sud. In Eaux et Territoires (3rd éd., pp. 413-424). Presses de l’Université du Québec. https://doi.org/10.2307/j.ctv18ph3zj.21

Dolatyar, M., \& Gray, T. S. (2000). The Politics of Water Scarcity in the Middle East. Environmental Politics, 9, 65-88. https://doi.org/10.1057/9780230599871

Erdinger, L., Hollert, H., \& Eckl, P. (2019). An Ecological Disaster Zone with Impact on Human Health: Aral Sea. In Encyclopedia of Environmental Health (pp. 87-94). Elsevier. https://doi.org/10.1016/B978-0-12-409548-9.11727-0

Farzaneh, R.-F., Liz, C., \& Souza, D. R.-M. (2002). Finding the Balance: Population and Water Scarcity in the Middle East and North Africa.

https://www.semanticscholar.org/paper/Finding-the-balance\%3A-population-and-wat er-scarcity-Roudi-Fahimi-Creel/c8247f3e4eca5b2f16058759d86ca99f3866709d

Fleming, J. (2021). Why Are the Rio Grande and Other Rivers Drying Up? https://www.liberationnews.org/why-are-the-rio-grande-and-other-rivers-drying-up

Geneva Water Hub (2015). Bibliographie. Conflits et coopération liés à l'eau. https://www.genevawaterhub.org/sites/default/files/atoms/files/biblio_waterconflictcoo peration_fr_0.pdf

Gleick, P. (1993). Water and Conflict, Fresh Water Resources and International Security. International Security, 18, 79-112. https://doi.org/10.2307/2539033

Goldstone, J. A. (2019). Africa 2050: Demographic Truth and Consequences. https://www.hoover.org/research/africa-2050-demographic-truth-and-consequences

Grasso, V. (2021). State of Climate Services Report: Risk Information and Early Warning Systems. Lucerne Switzerland. https://doi.org/10.5194/egusphere-egu21-74

Hammer, J. (2013). Is a Lack of Water to Blame for the Conflict in Syria? https://www.smithsonianmag.com/innovation/is-a-lack-of-water-to-blame-for-the-con flict-in-syria-72513729

Harris, W. W. (1978). War and Settlement Change: The Golan Heights and the Jordan Rift, 1967-77. Transactions of the Institute of British Geographers, 3, 309. https://doi.org/10.2307/622159

Heathershaw, J. (2010). Conflict Transformation in Central Asia: Irrigation Disputes in the Ferghana Valley. Central Asian Survey, 29, 133-135.

https://doi.org/10.1080/02634931003765605

Hoekstra, A. Y., Mekonnen, M. M., Chapagain, A. K. et al. (2012). Global Monthly Water Scarcity: Blue Water Footprints versus Blue Water Availability. PLoS ONE, 7, e32688. https://doi.org/10.1371/journal.pone.0032688

IAGF (2020). L'eau au cour des tensions entre le Mexique et les Etats-Unis. https://www.initiativesfleuves.org/actualites/leau-coeur-tensions-entre-mexique-etatsunis

INED (2021). Afrique orientale-Estimations 2021. https://www.ined.fr/fr/tout-savoir-population/chiffres/tous-les-pays-du-monde/?lst_co 
$\underline{\text { ntinent }=903 \& 1 s t \_p a y s=910}$

International Conference on Lake Chad (2018). Abuja Declaration. Abuja. https://www.waterresources.gov.ng/downloads

International Crisis Group (2018). Stopping Nigeria’s Spiralling Farmer-Herder Violence. Brussels.

International Monetary Fund (2018). The Federal Democratic Republic of Ethiopia: 2017 Article IV Consultation-Press Release; Staff Report; and Statement by the Executive Director for the Federal Democratic Republic of Ethiopia. Washington DC. https://www.imf.org/en/Publications/CR/Issues/2018/01/24/The-Federal-DemocraticRepublic-of-Ethiopia-2017-Article-IV-Consultation-Press-Release-Staff-45576

Islam, M. R. (1987). The Ganges Water Dispute: An Appraisal of a Third Party Settlement. Asian Survey, 27, 918-934. https://doi.org/10.2307/2644864

Italian Republic (2018). Memorandum of Understanding on Cooperation in the Field of Climate Change, Vulnerability, Risk Assessment, Adaptation and Mitigation between the Ministry for the Environment, Land and Sea of the Italian Republic (IMELS) and the Lake Chad Basin Commission. Rome.

https://www.gcc-sg.org/eng/index0cac.html?action=Sec-Show\&ID=486

Jones, E. G., \& Lineweaver, C. H. (2010). To What Extent Does Terrestrial Life "Follow the Water"? Astrobiology, 10, 349-361. https://doi.org/10.1089/ast.2009.0428

Kandeel, A. (2017). Climate Change: The Middle East Faces a Water Crisis. https://www.mei.edu/publications/climate-change-middle-east-faces-water-crisis

Kelley, C. P., Mohtadi, S., Cane, M. A. et al. (2015). Climate Change in the Fertile Crescent and Implications of the Recent Syrian Drought. Proceedings of the National Academy of Sciences of the United States of America, 112, 3241-3246. https://doi.org/10.1073/pnas.1421533112

Kongo, R. (2021). Transfèrement des eaux du fleuve Congo, un danger pour la RDC. https://www.mediacongo.net/article-actualite-83423_transferement_des_eaux_du_fleu ve_congo_un_danger_pour_la_rdc.html

Krutov, A., \& Spoor, M. (2003). XI. The "Power of Water" in a Divided Central Asia. Perspectives on Global Development and Technology, 2, 593-614. https://doi.org/10.1163/156915003322986415

Krzymowski, A. (2019). Water as a Weapon of War in the Tigris-Euphrates Basin. Przegląd Strategiczny, 12, 319-334. https://doi.org/10.14746/ps.2019.1.20

Larry, S. A. (2015). Water Conflict and Cooperation in Southern Africa. Wiley Interdisciplinary Reviews: Water, 2, 215-230. https://doi.org/10.1002/wat2.1070

Lavariega Monforti, J., \& Graham, M. A. (2018). The Rio Grande. In Latino Studies (pp. 1-16). Oxford University Press. https://doi.org/10.1093/obo/9780199913701-0134

Makengo, B. M. (2020). Competitive Globalization and Quest for Strategic Minerals: DRC's Cobalt at the Heart of New Global Stakes, towards the Resource's Trap? International Journal of Management Sciences and Business Research, 9, 51-75.

Mbutamuntu, J.-M., \& Mimbale, M. J. (2021). Le Droit Des Cours d'eau Internationaux. Connaissan.

https://www.connaissances-savoirs.com/le-droit-des-cours-d-eau-internationaux-jeanmarie-mbutamuntu-et-joseph-mimbale.html

McCracken, M., \& Wolf, A. T. (2019). Updating the Register of International River Basins of the World. International Journal of Water Resources Development, 35, 732-782. https://doi.org/10.1080/07900627.2019.1572497

McFadden, C. (2020). 11 Rivers Facing a Danger of Drying Up in America. 
https://interestingengineering.com/world-water-day-11-rivers-facing-a-danger-of-dryi ng-up-in-america

Mimbale, J. (2021). The Transaqua Project: Narrative and Constructivist Analysis. Academia Letters (AL3500). https://doi.org/10.20935/AL3500

Ministère de la Transition écologique de la France (MTEF) (2021). Observations du changement climatique.

https://www.statistiques.developpement-durable.gouv.fr/edition-numerique/chiffres-cl es-du-climat/1-observations-du-changement-climatique\#: :text=DepuislafinduXIX, $0 \%$ $\underline{2 \mathrm{C} 97 \mathrm{C}}$

Mirumachi, N. (2015). Transboundary Water Politics in the Developing World. Routledge. https://doi.org/10.4324/9780203068380

Mokry, M. (2021). Colorado Water. Diss. Colo. https://mountainscholar.org/bitstream/handle/10217/233888/UPUB_CW_Jun_38_01_ 2021.pdf?sequence $=1$

Moret, A. (2013). The Nile and Egyptian Civilization. Routledge. https://doi.org/10.4324/9781315005454

Mumme, S. P. (2020). The 1944 Water Treaty and the Incorporation of Environmental Values in U.S.-Mexico Transboundary Water Governance. Environmental Science \& Policy, 112, 126-133. https://doi.org/10.1016/j.envsci.2020.05.001

Musavuli (2018). RD Congo: Le projet Transaqua et la guerre de l'eau. https://www.agoravox.fr/actualites/international/article/rd-congo-le-projet-transaquaet-la-202001

Nunan, T. (2013). Ferghana Valley: The Heart of Central Asia. Europe-Asia Studies, 65, 1231-1232. https://doi.org/10.1080/09668136.2013.815032

Oki, T. (2006). Global Hydrological Cycles and World Water Resources. Science, 313, 1068-1072. https://doi.org/10.1126/science.1128845

Petersen-Perlman, J. D., Veilleux, J. C., \& Wolf, A. T. (2017). International Water Conflict and Cooperation: Challenges and Opportunities. Water International, 42, 105-120. https://doi.org/10.1080/02508060.2017.1276041

Procházka, P., Hönig, V., Maitah, M. et al. (2018). Evaluation of Water Scarcity in Selected Countries of the Middle East. Water, 10, 1482. https://doi.org/10.3390/w10101482

Ren, L., Xue, L., Liu, Y. et al. (2017). Study on Variations in Climatic Variables and Their Influence on Runoff in the Manas River Basin, China. Water, 9, 258. https://doi.org/10.3390/w9040258

Reuveny, R., \& Maxwell, J. W. (2001). Conflict and Renewable Resources. Journal of Conflict Resolution, 45, 719-742. https://doi.org/10.1177/0022002701045006002

Rodman, D. (2019). Self-Determination, Statehood, and the Law of Negotiation: The Case of Palestine. Israel Affairs, 25, 400-409. https://doi.org/10.1080/13537121.2019.1577601

Schleussner, C.-F., Donges, J. F., Donner, R. V. et al. (2016). Armed-Conflict Risks Enhanced by Climate-Related Disasters in Ethnically Fractionalized Countries. Proceedings of the National Academy of Sciences, 113, 9216-9221. https://doi.org/10.1073/pnas.1601611113

Schmidt, K. J. (2015). Partition of India, 1947. In An Atlas and Survey of South Asian History (pp. 98-99). Routledge. https://doi.org/10.4324/9781315706429-46

Sela, A., \& Yakira, E. (2003). La religion dans le conflit israélo-palestinien. Cités, 14, 13. https://doi.org/10.3917/cite.014.0013 
Seliktar, O. (2005). Turning Water into Fire: The Jordan River as the Hidden Factor in the Six-Day War. Middle East Review of International Affairs, 9, 57-71.

Shiklomanov, I. A. (1998). World Water Resources: A New Appraisal and Assessment for the 21st Century. UNESCO International Hydrological Programme, UNESCO-IHP.

Szabo, S. (2011). "The Water Challenge in the UAE”-Water Is Life's Mater and Matrix, Mother and Medium. There Is No Life without Water. Dubai School of Government, 1, $1-8$.

https://www.researchgate.net/publication/251493515_The_water_challenge_in_the_U $\underline{\mathrm{AE}}$

The Guardian (2015). "We Woke Up in a Desert"-The Water Crisis Taking Hold across Egypt.

https://www.theguardian.com/world/2015/aug/04/egypt-water-crisis-intensifies-scarcity

The National Geographic (2017). Climate Change and Water Woes Drove ISIS Recruiting in Iraq.

https://www.nationalgeographic.com/science/article/climate-change-drought-drove-isi s-terrorist-recruiting-iraq

The National Geographic (2019). Environnement: Ces rivières s'assèchent dangereusement.

https://www.nationalgeographic.fr/photography/2019/03/environnement-ces-rivieres-s assechent-dangereusement?image $=$ drawn-river-dry-river-341549-7607930

The National Geographic (2021). Two-Thirds of the Longest Rivers No Longer Flow Freely-And It's Harming Us.

https://www.nationalgeographic.com/environment/article/worlds-free-flowing-riversmapped-hydropower

The World Bank (2021). Water-Overview.

https://www.worldbank.org/en/topic/water/overview\#1

Tshibwabwa, S. (2017). After Plundering Minerals, Soon the Plundering of the Congo Freshwater, the Blue Gold of This Century.

https://afridesk.org/en/after-plundering-minerals-soon-the-plundering-of-the-congo-f reshwater-the-blue-gold-of-this-century-sinaseli-tshibwabwa

UNFCCC (2021). Une température supérieure que $1.5^{\circ} \mathrm{C}$ dans les cinq prochaines années, selon de nouvelles prévisions du climat.

https://unfccc.int/fr/news/une-temperature-superieure-que-15-degc-dans-les-cinq-pro chaines-annees-selon-de-nouvelles-previsions

U.S. Geological Survey (2021). How Much Water Is There on, in, and above the Earth? https://www.usgs.gov/special-topic/water-science-school/science/how-much-water-the re-earth?qt-science_center_objects=0\#qt-science_center_objects

United Nations (2020). Pénurie d'eau. https://www.un.org/fr/waterforlifedecade/themes/scarcity.shtml

Warner, J. (2012). Three Lenses on Water War, Peace and Hegemonic Struggle on the Nile. International Journal of Sustainable Society, 4, 173. https://doi.org/10.1504/IJSSOC.2012.044672

Warren, A. (n.d.). Arid Zone Management and Problems. In Environmental Geology (pp. 33-35). Kluwer Academic Publishers. https://doi.org/10.1007/1-4020-4494-1_21

Westall, F., \& Brack, A. (2018). The Importance of Water for Life. Space Science Reviews, 214, 50. https://doi.org/10.1007/s11214-018-0476-7

WMO (2021). 2020 est l'une des trois années les plus chaudes jamais enregistrées. https://www.europarl.europa.eu/news/fr/headlines/society/20180301STO98928/emissio 
ns-de-gaz-a-effet-de-serre-par-pays-et-par-secteur-infographie

Wolf, A. (1998). Conflict and Cooperation along International Waterways. Water Policy, 1, 251-265. https://doi.org/10.1016/S1366-7017(98)00019-1

Wolf, A. T., Kramer, A., Carius, A., \& Dabelko, G. D. (2005). Managing Water Conflict and Cooperation. In State of the World 2005: Redefining Global Security (pp. 80-95). Earthscan.

Woodhouse, C. A., \& Pederson, G. T. (2018). Investigating Runoff Efficiency in Upper Colorado River Streamflow over Past Centuries. Water Resources Research, 54, 286-300. https://doi.org/10.1002/2017WR021663

Xenarios, S., Shenhav, R., Abdullaev, I. et al. (2018). Current and Future Challenges of Water Security in Central Asia. In Global Water Security (pp. 117-142). Springer. https://doi.org/10.1007/978-981-10-7913-9_5

Yalchin, M. (2011). Géopolitique des barrages turcs sur le Tigre et l'Euphrate. EuroCité (Note No. 6).

https://www.academia.edu/29765629/GÉOPOLITIQUE_DES_BARRAGES_TURCS_S

UR_LE_TIGRE_ET_LEUPHRATE 